\title{
ТАНЕЦЬ ТА ЕКРАННІ МИСТЕЦТВА: ЗАПОЧАТКУВАННЯ І РОЗВИТОК КОНТАКТІВ
}

У статті розглядається еволюиійний проиес у співтворчості танцฺю та екранних мистеитв кіно, телебачення: від перших спроб фіксаиії танців на кіноплівиі, започаткування і розвитку різних жанрів (ревю, екранізація балету, фільм-портрет, мюзикл) до появи таких експериментальних прачь, як кінотанеиь, телебалет.

Ключові слова: танець, кіно, телебачення, хореограф, екранізачія, крупний план, рапід, монтаж, мюзикл, кінотанець, телебалет.

В статье рассматривается эволючионный процесс в сотворчестве таниа и экранных искусств кино, телевидения: от первых опытов фиксации танщев на киноплёнке, зарождения и развития разных жанров (ревю, экранизация балета, фильм-портрет, мюзикл) до появления таких экспериментальных работ, как кинотанеи, телебалет.

Ключевые слова: танеи, кино, телевидение, хореограф, экранизация, крупный план, рапид, монтаж, мюзикл, кинотанеи, телебалет.

This article examines the evolutional process in co-authorship of dance and screen arts such as cinema and television from the first tests of fixation of dance on the film, conception an development of different genres such as review, screening of ballet, film-portrait, musical and appearance of such experimental works as dance in cinema and television ballet.

Key words: dance, cinema, television, choreographer, screening, close-up, editing, rapid, musical, dance in cinema, television ballet.

Кіно, як синтетичне мистецтво, спирається на традиції літератури, театру, живопису, музики. Воно багато що вбирає до себе, однак не викликає ніяких руйнувань у жодному жанрі мистецтва. Разом з тим, кіно може взяти на себе певні сторони того чи іншого мистецтва і надати їм нових якостей.

«Кінематограф ніби живиться традиціями інших мистецтв, - зазначав В. Пудовкін, - перетворюючи їх на особисті, нові» [1]. За словами видатного кінорежисера, «кінематограф певною мірою володіє силою безпосереднього впливу зоровим образом. Його вільний рух у часі може сповна використовувати і розвивати форми ритму, встановлені музикою та поезією. Він повною мірою може зображати всю складність світу, робити зрозумілими глибокі зв'язки між явищами, легко переносячись у простір і легко повертаючись у часі. Він однаково чітко бачить і деталь, і те загальне, до чого вона належить» [1].
I хоч ці висловлювання В. Пудовкіна про кінематограф стосувалися літератури, театру, живопису, музики, проте їх можна віднести й до танцювального мистецтва.

Здавалося б, екранні мистецтва - кіно, телебачення - далекі від танцю, однак вони також взаємодіють 3 ним. Це і використання тих чи інших компонентів кіно й телебачення у художньому оформленні балетної вистави, це й екранізації балетів класичної спадщини та сьогодення, а також створення телебалетів і кінофільмів, що вибудувані за законами хореографії та екранних мистецтв.

Перші спроби зафіксувати танець на кіноплівці були здійснені ще до появи кінематографа. Так, у 1894 році Томас-Алва Едісон (винахідник фонографа) зняв на кінетоскопі фільм «Танець змії», а в 1899-му Жорж Мельєс (механік, художник, фокусник, актор, письменник) зафіксував фрагмент балету «Попелюшка». 
Впродовж усієї історії німого кіно робилися спроби ввести танець до художньої тканини фільму. В Росії навіть були зняті фільми-балети (без звуку) «Коппелія» Деліба (1913, за участю Катерини Гельцер) й «Азіаде» (1918, Маргарита Фроман та Михайло Мордкін). До епохи німого кіно належать і перші досліди фіксації балетів 3 навчальною та документальною метою. Щодо цього особливий інтерес становлять декілька документальних фрагментів, які були зняті за ініціативою відомого американського актора Дугласа Фербенкса; серед них - танець Анни Павлової.

3 появою звуку в кіно одним з найбільш популярних жанрів американського кінематографа став фільм-ревю. Передусім тут слід назвати ім'я продюсера Флоренца Зігфелда, який вже мав великий досвід роботи у мюзик-холі. Він розпочав свою кар'єру як антрепренер найсильнішої людини у світі - Свгенія Сандова - і завершив власником найбільшого бродвейського театру. На його грандіозній сцені були здійснені постановки надзвичайних за красою і помпезністю вистав за участю зірок естради (співаків, танцівників), відомих майстрів спорту; вартість постановок сягала 175.000 доларів. Такі вистави-ревю, відомі під назвою «Зігфелд-фоліс», були надзвичайно популярні у 1907-1931 роках.

Флоренцові Зігфелду американські кінематографісти присвятили декілька кінострічок, зокрема «Великий Зігфелд» (1936, режисер Роберт 3. Леонард, хореограф Сеймур Фелікс) i «Безумства Зігфелда» (1946, режисер Вінсенте Міннеллі, хореографія Роберта Олтона, музика і тексти Джорджа та Іри Гершвін). Це фільм-концерт, створений з номерів різних шоу, ревю у постановці Зігфелда. У фільмі задіяні зірки американської естради: Фред Астер, Люсіль Бремер, Мерилін Міллер, Вілл Роджерс, Естер Вільямс, Едді Кантор, Джин Келлі, Джуді Гарланд та ін.

Високим рівнем хореографії та творчої фантазії відзначені фільми 30-х років, створені режисером Ллойдом Беконом і балетмейстером Басбі Берклi: «42-а вулиця», «Перед вогнями рампи» (1933), «Чудо-бар» (1934). Серед фільмів-ревю вирізнялися й такі, як «Золотошукачка» (1933, 1935, 1937), «Бродвейська мелодія 1936 року». У кінострічках режисера Д. Маршалла танці поставив видатний хореограф Джордж Баланчин. Це «Голдвін-Фолліз» (1938), «На пуантах» (1939), «Я була шукачкою пригод» (1940), «Зірково-смугастий ритм» (1943).
3 фільмами-ревю суперничали музичні кінострічки за участю відомої танцювальної пари Джинджер Роджерс і Фреда Астера: «Політ до Ріо» (1933), «Веселе розлучення» (1934), «Роберта» і «Циліндр» (1935), «Ритм свінгу» (1936), «Потанцюємо?» («Давайте потанцюємо», 1937), «Безтурботний» (1938), «Історія про Вернона і Айрін Кастл» (1939).

Саме цьому періоду взаємин балету і кіно присвячена значна частина американського фільмy «That's dancing!» («Це танець!», 1985): композитор Генрі Манчінні, виконавчий продюсер Джин Келлі - одна 3 танцювальних зірок 30 -х-40-х років XX ст..

У Франції жанр кіно-ревю не мав поширення. Там для участі у художніх фільмах запрошувалися танцівники паризької Гранд-опера. Це «Умираючий лебідь» (1937) режисерів Ж. Бенуа-Леві та М. Епштейн з балетмейстером Сержем Лифарем і танцівниками Міа Славенською, Іветт Шовіре, Жанін Шарра. Іветт Шовіре також брала участь у кінокартині «Гріх молодості» (1942). Людмила Черіна (вихованка Ольги Преображенської) знімалась у фільмах «Повернутий» (1946), «Ось вона, Красуня» (1950), «Гран-Гала» (1953). Танцівник Мішель Рено знявся у кінострічці «Капітан» (1945).

Від початку 50-х років у США набули чималого поширення музичні фільми та мюзикли, хореографами яких були Майкл Кідд («Сім наречених для семи братів», 1954; «Зірка», 1968), Герберт Росс («Смішне дівчисько» 3 Барбарою Стрейзанд, 1968; «Пенні з неба», 1981), Роберт (Боб) Фосс («Любка Черіті», 1968; «Кабаре», 1972; «Увесь цей джаз», 1980), Джером Роббінс («Вестсайдська історія», 1961; «Моя чарівна леді», 1964; «Скрипаль на даху», 1970).

Великою популярністю користувались музичні фільми танцівника і хореографа Джина Келлі: «Матроси на березі» та «Звільнення у місто» (1949), «Американець у Парижі» (1951), «Співи під дощем» (1952), «Бригадун» (195455), «Завжди гарна погода» (1955), «Запрошення до танцю» (1956), «Дівчата з Рошфора» (1967), «Хелло, Доллі!» (1969), «Ксанду» (1980, диско-фільм).

У кількох американських і французьких кінокартинах хореографом був відомий балетмейстер Ролан Петі: «Ханс Кристіан Андерсен» (1951), «Все мине» (1956), «Фолі̀ Бержѐр» (1956). Він також був постановником фільмів-балетів: «Кришталевий черевичок» (1954), «Чорні трико» («Раз, два, три, чотири», 1960). 
Відомий іспанський танцівник і хореограф Антоніо Гадес поставив танці у стилі фламенко у фільмі режисера Карлоса Са̀ури «Криваве весілля» за драмою Ф. Гарсіа Лорки (1981). У кінострічці йдеться про те, як балетна трупа під керівництвом Гадеса проводить репетиції та виконує драму Лорки. Засобами двох мистецтв - балету й кіно - у поетичних образах відтворена глибина народної трагедії, цілеспрямованість героїв до кохання і свободи.

У Радянському Союзі, починаючи 3 кінця 1930-х років, створювалися фільми-концерти, до яких включали окремі балетні номери у виконанні видатних танцівників, а також кінострічки, що вміщували великі фрагменти 3 класичних балетів. Всі вони становлять документальну цінність для історії балету. Так, фільм «Майстри російського балету» (1954) - це монтаж балетів «Лебедине озеро» П. Чайковського (танцюють Г. Уланова, Н. Дудинська, К. Сергєєв), «Бахчисарайський фонтан» (Г. Уланова, М. Плісецька, П. Гусєв, Ю. Жданов) і «Полум’я Парижа» (В. Чабукіані, М. Готліб) Б. Асаф'єва.

1950-ті-70-ті роки позначені низкою цікавих екранізацій балетів С. Прокоф'єва: «Ромео і Джульєтта» (1956; Г. Уланова та Ю. Жданов, балетмейстер Л. Лавровський) і «Кришталевий черевичок» (1961; Р. Стручкова, хореограф Р. Захаров), «Лебедине озеро» П. Чайковського (1957; М. Плісецька, М. Фадєєчев), «Лілея» К. Данькевича (1959; С. Єршова, Р. Візиренко-Клявін, балетмейстер В. Вронський), «Венеціанський мавр» О. Мачаваріані («Отелло», 1961; виконавець головної партії та хореограф В. Чабукіані), «Анна Кареніна» Р. Щедріна (1976; М. Плісецька, М. Лієпа, Н. Сорокіна; балетмейстери М. Плісецька, Н. Риженко, В. Смирнов-Голованов), «Спартак» А. Хачатуряна (1965; Н. Безсмертнова, В. Васильєв, Н. Тимофєєва, М. Лієпа; хореограф Ю. Григорович) тощо.

Взаємодія балету і кіно в екранізаціях відбувалася, по суті, двома шляхами. Перший - це механічне перенесення балетної вистави на екран (збереження сценічного майданчика, умовних декорацій). Другий шлях - урахування при екранізації специфіки кіномистецтва: натурні зйомки, ракурси, крупні плани, збагачення зорового ряду деталями, ідеальне ритмічне злиття руху камери і музики. Відповідно до вимог кінематографа також перероблялися сценарії, планувальні рішення сценографії, змінювалися за потреби просторові рішення мізансцен. До вимог та умов кінозйомки пристосовувались засоби акторської гри й танцювальної техніки.
Наступний етап співпраці танцювального i кіномистецтва - мюзикл. Це синтетичний жанр, в якому специфічними засобами кіномистецтва втілений драматичний сюжет, що базується на відносно рівних засадах співіснування драматичної діï, співу, танцю. Кожний з цих компонентів $є$ важливим структурним елементом. Органічно синтезуючи ці елементи, мюзикл примушує просувати розвиток дії властивими їм способами, утворюючи сцени безперервного розвитку дії, висловлюючи наскрізну думку, що динамічно розвивається. Це так звана «комплексна» драматургія.

Функція хореографії - подавати власний коментар подіям, характерам героїв, наголошувати кульмінації, за допомогою яскравих асоціацій надавати більшої об'ємності образам твору. Хореографія, як активний творець кіномюзиклу, користується усією пластично-танцювальною багатобарвністю: класичний танець і акробатичний, народний танець (сольний і масовий) та бальний (особливо заснований на латиноамериканських ритмах), пантоміма і жест (зокрема шаржований) та ін.

Балетмейстер кіномюзиклу фактично виступає рівноправним співавтором режисера-постановника: це Роберт (Боб) Фосс («Кабаре» Дж. Кандеpa і Ф. Ебба), «Чикаго» Дж. Кандера («Увесь цей джаз»); Джером Роббінс («Вестсайдська історія» Л. Бернстайна, «Моя чарівна леді» Ф. Лоу, «Людина з Ламанчі» М. Лі); Марко Бро («Звуки музики» Р. Роджерса і О. Хаммерштайна); Онна Вайт («Олівер!» Л. Барта); Дж. Лінн («Сats» Е. Л. Веббера) та ін.

Багатство барв, ритмів, рухів, властивих хореографії, у поєднанні з суто кінематографічними засобами виразності (крупний план, наплив, паралельний монтаж, ракурс) сприяють створенню яскравих образів і зорового ряду в кіномюзиклах.

Досить рідкісне поки що явище - танець як основа кінодії: жодного слова, лише музично-хореографічна драматургія з урахуванням специфіки екрана. Приклад - фільм «Бал» італійського сценариста і кінорежисера Eтторе Скола. (Провісником цього кінотвору можна вважати фільм 1960 року режисера Джо Янга і хореографа Ролана Петі «Чорні трико»). Кінострічка, створена у Франції у 1983 році, отримала спеціальний приз Міжнародного кінофестивалю у Берліні (1984). У фільмі оповідається про групу людей, які постійно збираються у танцювальній залі упродовж кількох десятиліть: 3 кінця 20 -х років до 70-х (включно). Їхні долі, стосунки за різних часів - довоєнні роки, період Другої світової війни, 
повоєнні часи, суспільно-громадянські явища, як-от ставлення до латиноамериканців та людей інших національностей, подані через танці, пантоміму, пластику. До того ж, відібрані танці, що побутували за певних часів, тобто через танці подана характеристика не лише персонажів, а й епохи, місця і часу дії. Їх аранжування, як і написання музики низки танцювальних номерів, здійснив французький композитор Владимір Косма̀.

На телеекрані хореографічні номери 3'явились наприкінці 1930-х - початку 40-х років. Функція телебачення полягала в тому, щоб знайомити глядачів з балетом. Раніше це робило радіо, телебачення ж тепер давало змогу побачити мистецтво танцю. Концертні виступи видатних балерин і танцівників транслювалися безпосередньо 3 телестудії. В них брали участь Г. Уланова, М. Семенова, О. Лепешинська, Н. Дудинська, К. Сергєєв, С. Корінь та інші.

Вже у 1940 році функціонував «Телевізійний театр мініатюр», де співіснували класика, характерний танець, оперета, естрада, розмовні номери. Програми об'єднувалися певною темою та конферансом ведучих. В освітніх передачах драматичні епізоди сусідували з балетними номерами, постановниками яких у 50-ті роки були такі майстри, як Ю. Григорович та Л. Якобсон.

3 1950-х років телебачення почало знайомити глядачів не лише з окремими танцювальними номерами, а й із повноцінними виставами. Вони транслювалися безпосередньо 3 театру, і глядачі могли почуватися присутніми у залі (чути настроювання інструментів в оркестрі перед початком вистави, реакцію глядацької зали, аплодисменти).

Поступово поставали проблеми, викликані вимогами телебачення. Насамперед вони стосувалися грамотності телезйомок, тобто роботи телеоператорів: виникли питання що і як показувати. Потрібно було враховувати той чи інший хореографічний стиль і обирати відповідні телевізійні засоби. Це стосувалось і прийому «крупного плану». Адже якщо на виставі глядачі самі обирають крупний план різних танцівників, балетних сцен, то при телетрансляції цей вибір залежить від грамотності телережисера і телеоператора.

Важливий для телекамери й вибір виконавця у певний момент, його міміка (не треба, скажімо, зосереджувати увагу на зусиллях і труднощах). Показуючи масові сцени, слід обирати чи загальний план, чи окремі групи. Для цього слід попередньо ознайомитись із задумом і постановкою хореографа.
Телебачення не лише ставило вимоги до балетних вистав, а й розширювало рамки їх сприйняття, застосовуючи різні технічні засоби. Так, нехтуючи законами тяжіння, танцівник може виникнути раптово, як привид, або з'явитися у кадрі згори чи знизу. Можна застосовувати прийом подвійної експозиції (одночасно в кадрі задній план і передній), розташування сценічних майданчиків на різних рівнях, рапід тощо.

Поступово телебачення урізноманітнювало жанри балетних телепередач. Це і хроніка - про нові постановки, світ закулісся, інтерв'ю з балетмейстерами, танцівниками, балеринами. Це i документалістика, науково-популярні телефільми. За приклад можуть слугувати фільми-портрети, створені режисером Ю. Альдохіним, - цикл «Створення танців»: «Роздуми про балет» (про Касьяна Голейзовського), телефільми про хореографів Ю. Григоровича і О. Виноградова, телепередачі про видатних балерин і танцівників - Biолету Бовт («Інтерв’ю, якого не було»), Галину Уланову (репетиції), Володимира Васильєва і Катерину Максимову («Дует»). Це також фільми-портрети інших авторів: «Майя Плісецька» В. Катанян, «Життя у танці» (про Ю. Григоровича і Н. Безсмертнову) В. Граве та ін.

Для самоствердження балету на телебаченні потрібні були оригінальні, спеціально створені постановки, в яких би поєднувалися закони як балетної драматургії, так і мистецтва телебачення. Проте таких можливостей телебачення на той час іще не мало.

Лише наприкінці 50-х років (1959) з'явився перший телебалет, створений на Центральній студії телебачення, - «Граф Нулін» Б. Асаф'єва, за поемою О. Пушкіна, сценарист і балетмейстер-постановник В. Варковицький, оператор Д. Зайцев, художники К. Єфімов та С. Петерсон. У ролях: О. Лепешинська, С. Корень, О. Радунський, Я. Сангович, Е. Кашані та інші. Цей телебалет за стилем наближається до хореодрами, в якій важливу роль, окрім танцю, відіграє пантоміма. Щодо телевізійних прийомів, то дія розгорталась у натуральних інтер'єрах, з великою кількістю крупних планів, відмовою від театральності. Цікаво була використана мультиплікація: прийом «живого» пера у титрах - заставці (назва телебалету на сторінках розкритої книги) і у фінальних кадрах (слово «кінець» так само). С тут і звернення до засобів ігрового кіно без включення танців, введення панорам пейзажів до танцювальних епізодів, прийом паралельного монтажу, що посилило динамічність хореографічної дії. 
Наступний телебалет 3'явився лише наприкінці 60-х років: «Ромео і Джульєтта» (1968) на музику увертюри-фантазії П. Чайковського за Шекспіром. Сценаристи і балетмейстери Н. Риженко і В. Смирнов-Голованов, оператор В. Железняков, художник В. Левенталь; у головних ролях: Н. Безсмертнова, М. Лавровський.

Постановка цього телебалету, з одного боку, близька театральній поетиці, адже спочатку це був задум постановки на сцені театру: фронтально побудовані мізансцени й хореографічні композиції, певна театральність художнього рішення (сцена-коробка, незмінність декорацій упродовж дії тощо). 3 іншого - постановка пов'язана 3 телевізійною специфікою: використання рапіду, напливу, динамічного монтажу, крупного плану, подвійної та потрійної експозицій.

Так, в адажіо Ромео і Джульєтти вперше у телебалетах був застосований рапід, що створив відчуття нескінченно-просторового буяння закоханих і став надзвичайно співзвучним емоційно-виразній музиці Чайковського. Динаміку танцювальних фрагментів, контраст ліричних і драматичних сцен посилили монтаж, техніка зйомок.

Надалі Н. Риженко і В. Смирнов-Голованов разом з творчим об'єднанням «Екран» неодноразово зверталися до жанру телебалету: «Трапеція» на музику С. Прокоф’єва (1970), «Пустотливі частівки» Р. Щедріна (1970), «Білі ночі» на музику секстету «Просвітлена ніч» А. Шонберга (1972), «Федра» О. Локшина (1972), «Московська фантазія» В. Артемова (1972).

Приклад поєднання на телеекрані різних видів мистецтва (літератури, музики, балету, драматичного театру, телемистецтва) - «Фантазія» (1976), поставлена театральним режисером Анатолієм Ефросом за мотивами роману I. Тургенєва «Весняні води» («Вешние воды»); хореографія Валентина Єлізарьєва. У головних ролях - Майя Плісецька та Інокентій Смоктуновський. Сюжет розгортається у двох площинах: драматичного мистецтва - зовнішні події, мовою хореографії - внутрішнє життя героїв. Балетні сцени - це не просто ілюстрація драматичних подій. Пластикою висловлені емоції героїв, їх пристрасті, підсвідоме прагнення одне до одного.

Подальші пошуки у жанрі телебалету пов'язані з Ленінградським (нині Петербурзьким) телебаченням, $з$ ім'ям режисера Олександра Бєлінського. Він співпрацював на Лентелефільмі з такими хореографами, як Д. Брянцев, В. Васильєв. Перша спільна робота режисера була з Д. Брянце- вим - «Галатея» (1977) за мотивами п’єси Б. Шоу «Пігмаліон» і музикою мюзикла Ф. Лоу «Моя чарівна леді» (у довільному аранжуванні Т. Когана); оператор С. Черняк, художник Л. Луконіна. У ролях: К. Максимова, М. Лієпа, В. Гуляєв, В. Кузнєцов та інші. Якщо у Лоу та мюзиклі професор фонетики Генрі Гіггінс навчає продавщицю квітів Елізу Дулітл правильній англійській вимові для того, щоб потім у вищому світі представити іiі як герцогиню, то в сценарії телебалету Гіггінс дає Елізі уроки класичного танцю, навчаючи хореографічній мові.

О. Бєлінський і Д. Брянцев відмовились від різних телеефектів: комбіновані зйомки, зміна ракурсів, наплив тощо. Лише тричі й досить обережно був використаний рапід. Це були повторені в уповільненому темпі танцювальні рухи, що раніше подавалися на екрані у звичайному темпоритмі.

Цій постановчій групі належить ще один телебалет - «Старе танго» (1979). У сценарії використані сюжетні мотиви кінофільму «Петер» (1934). Т. Коган написав музику, стилізовану під популярні танцювальні мелодії та ритми 20-х-30-х років (танго, чарльстон, тустеп тощо), а також увів до музичної тканини дві цитати з музики М. Бродського до кінострічки «Петер». Сам телебалет вирішений у стилі ретро.

Упродовж 1980-х років Олександр Бєлінський плідно працював у жанрі телебалету як сценарист і постановник. Його партнерами-хореографами були Г. Абайдулов, В. Васильєв. Найбільш плідною була співдружність Бєлінського з Володимиром Васильєвим. Це телебалети «Жиголо і жиголетта», «Анюта», «Дім біля дороги».

«Жиголо і жиголетта» (1980) створена за оповіданням Сомерсета Моема на музику Астора П'яццолли. У цій телевізійній роботі поєдналися виражальні засоби драматичного театру й кінематографа. Ролі у телебалеті виконували як танцівники - К. Максимова та В. Васильєв, так і драматичні актори - М. Миронова, М. Перцовський, Р. Ніфонтова, М. Підгорний тощо. Як і у «Фантазії,, сюжет поданий засобами балету і драми: реальне життя персонажів розкрите у діалогах, їх спогади - ігрова пантоміма, танець; це виправдано самим змістом оповідання: герої - професійні танцівники (жиголо і жиголетта - платні танцівники).

Взаємодія різних видів мистецтва для музично-хореографічного образного рішення літературних творів яскраво виявилась у телебалеті «Анюта» (1982) на музику Валерія Гавриліна (сцена- 
рій О. Бєлінського, постановники О. Бєлінський і В. Васильєв, хореографія В. Васильєва).

У хореографічному рішенні Васильєв поєднав виражальні засоби класичного танцю і хореодрами. Танцювально-пластична лексика головних персонажів (виконавці - Катерина Максимова, Володимир Васильєв, Галі Абайдулов) індивідуалізована. Це стосується і кордебалету, де кожен учасник має свою виразну пластику, зовнішні пристосування.

Для розкриття тих чи інших сцен застосовані різноманітні виражальні прийоми екранного мистецтва. Так, прийом напливу використаний у сценах снів головних героїв. Це сон Анюти, в якому оживає іiі минуле - дитинство, де вона танцює 3 матір'ю й батьком. Це й нереально-маячні видіння - мрії Модеста Олексійовича про орден Анни другого ступеня. Це також сон-примара Петра Леонтійовича, батька Анни, який поданий за допомогою напливу - оживлення старої фотосвітлини 3 сімейного альбому.

Цікаво застосований і прийом крупного плану ніг (він буде використаний і в телебалеті 1984 року «Дім біля дороги»). Передусім це сцена роботи чиновників: вони сидять за столами, передаючи один одному незримі папери, вдаряючи рукою по столу, імітуючи штампування. Водночас у цьому ж темпо-ритмі рухаються їхні ноги, подані крупним планом (що неможливо на сцені). Поступово рух ніг одного з чиновників уповільнюється і раптом зупиняється - чиновник заснув (крупний план переходить у середній) і зупинив цей бюрократичний механізм.

В основу сценарію «Дім біля дороги» (1984) була покладена однойменна поема Олександра Твардовського, яку сам поет назвав «ліричною хронікою».

Музику написав Валерій Гаврилін спеціально для телебалету. В ній відчутна фрагментарність, риси сюїтності, що виправдано виражальними засобами телебачення: кадрова побудова, напливи, монтаж спогадів і реальності тощо.

Телевізійні засоби виразності превалюють у більшості сцен-епізодів, як-от, показ крупним планом ніг танцівників у сцені сільського свята (ноги хлопців і дівчат, які вистукують під столом у такт музиці), підборів чобіт німців у сцені «Полон» (дві шеренги німців, одна проти одної, які підборами умисно-розмірено вистукують ритм музики). Своєрідна монтажна хореографія наявна в епізоді «Бій»: чергування рапідної зйомки стрибків або бігу персонажів 3 панорамою села, що огороджене колючим дротом.
Упродовж другої половини $1980-x$ років було створено ще низку оригінальних телебалетів: «Сині троянди для балерини» (1985; музика О. Бальчева, балетмейстери Н. Касаткіна і В. Васильов), «Принц і жебрак» (1985; композитор Н. Симонян, хореограф Н. Волкова), «Місячний вальс» (1986; музика I. Дунаєвського, сценарій i постановка О. Бєлінського, балетмейстер С. Виноградова), «Валенсіанська удова» (1986; композитор А. Хачатурян, хореографія Б. Барановського), «Чаплініана» (1987; кіномузика Чарлі Чапліна, сценарій і постановка О. Бєлінського, балетмейстер Г. Абайдулов).

Розвиток контактів та взаємодії танцю й екранних мистецтв викликав появу цілої низки цікавих експериментальних праць. Це постановки хореографа Модеста Пандлтона за участю балерини Діани Вишневи «Лебедині сни» і «Дзеркальне пробудження», балет «Шазам» хореографа Філіппа Декуфле. Це й роботи кінорежисера і відеохудожника Чарльза Атласа та хореографа Мерса Каннінгхема: «Блакитна студія» (1976), «Варіації Райнер» (2002) - відеопортрет режисера і хореографа Івонн Райнер, «Види на камері» та «Види на відео» (обидва 2005 року). Ці та низка новаторських творів у жанрі кінотанцю були створені Атласом на базі танцювальної трупи хореографа Каннінгхема (Merce Cunningham Dance Company), де він був постійним режисером (1974-1983), який відповідав за зйомки балетів цієї трупи. Його 90-хвилинний телевізійний фільм «Мерс Каннінгхем: життя у танці» (2000) був відзначений призом за найкращий документальний фільм на фестивалі у Монако «Танець на екрані» (Dance Screen).

У жанрі кінотанцю вирішена кінострічка «Канали/Вставки» (1981) - режисер, монтаж і костюми Чарльза Атласа, хореографія Мерса Каннінгхема. Музика композитора Девіда Тудора спрямувала постановників на пошуки своєрідного зорового ряду: приміщення, де розгортається дія (сцена, кімнати, коридори), костюми танцівників (спортивно-тренувальні), ритмічні рухи, жести й пози, що періодично повторюються (навіть без наявності музики).

Ч. Атлас співробітничав й з іншими хореографами, зокрема британцем Майклом Кларком. У 80-ті роки він зняв два телефільми на замовлення 4-го каналу в Лондоні, що базуються на роботах цього балетмейстера. Атлас - автор новаторських багатоканальних відеоінсталяцій, повнометражних документальних фільмів, творів відеоарту для телебачення та живих електронних перфомансів. 
Він був удостоєний багатьох нагород: тричі Призом «Бессі» («Bessie») в галузі театру й танцю у Нью-Йорку, призом американського композитора Джона Кейджа на Бієнале Фонду Сучасного Мистецтва.

Як бачимо, діалог танцю та екранних мистецтв (кіно, телебачення), їх взаємодія і взаємозбагачення - це характерна тенденція сьогодення.

\section{Джерела та література:}

1. Пудовкин В. О монтаже // В. Пудовкин. Избранные статьи. - М. : Искусство, 1965. - С. 107-108, 114.

\section{References}

1. Pudovkin, V. O montazhe // V. Pudovkin (1965) Izbrannyie stati. - M. : Iskusstvo. - S. 107-108, 114 [in Russian]. 